\title{
PENGANEKARAGAMAN KONSUMSI PANGAN RUMAH TANGGA MASYARAKAT PESISIR DI KOTA BENGKULU MELALUI TEKNOLOGI PENGOLAHAN PRODUK HASIL LAUT DAN NON HASIL LAUT
}

\section{DIVERSIFICATION OF HOUSEHOLD FOOD CONSUMPTION OF COASTAL COMMUNITIES IN BENGKULU CITY THROUGH PROCESSING TECHNOLOGY OF SEA PRODUCT AND NON MARINE PRODUCTS}

\author{
Oleh: \\ Reswita, Melli Suryanty, Ellys Yuliarti \\ Fakultas Pertanian Universitas Bengkulu \\ Email: reswita17@yahoo.co.id
}

\begin{abstract}
Food is an ingredient intended as food or beverage derived from biological and water resources, whether processed or unprocessed, including food additives, foodstuffs, and other materials used in the process of preparing, processing and / or making food and drink. To meet the nutritional needs of the family is very necessary for diversification of food consumption. The purposesof this community service is are 1) Providing knowledge and insight on the importance of diversification of household food consumption, 2) training on the manufacture of some processed products from seafood such as fish abon, fish rolade, and tuna meatballs, 3) Training on the manufacture of some processed products from non-marine products such as tubers combined with marine products such as tuber chips that have a taste of shrimp and sea fish can be utilized to meet family food consumption, 4) Training on the manufacture of some processed products from other nonmarine products, namely processed foods from tofu and tempeh, 5) Training on packaging techniques and product labeling so that this product can be sold and can increase the fishermen's household acceptance. The targets of this technology are PKK group mothers and young women in RT IV Kelurahan Malabero. The number of trainees is 20 people. From community service activities "Diversification of food consumption of coastal community households in bengkulu city through marine and non marine products processing technology" community, especially housewives and girls in RT. IV Malabero Kota Bengkulu gain additional knowledge and skills about making various products such as tuna shredded fish, tuna meatballs, tuna rolade, tempeh chips, cassava chips, sweet potato chips, satay tofu, and tempe brownees so it can be used in entrepreneurship.
\end{abstract}

Keywords: diversification of household consumption, marine products, Malabero

\section{PENDAHULUAN}

Rumah tangga yang telah tahan pangan dicirikan oleh terpenuhinya kebutuhan pangan, baik dari segi jumlah, mutu, keamanan pangan, merata, dan mampu menjangkau 
pangan tersebut. Pangan merupakan bahan yang diperuntukkan sebagai bahan makanan atau minuman yang berasal dari sumberdaya hayati dan air, baik yang diolah maupun tidak diolah, yang terdiri dari bahan baku pangan,bahan tambahan pangan,dan bahan-bahan lainnya yang digunakan dalam proses penyiapan, pengolahan, atau pembuatan makanan danminuman.Untuk mencukupi kebutuhan gizi rumah tangga sangat perlu adanya keanekargaman pangan yang dikonsumsi. Beranekaragamnya pangan yang dikonsumsi, selain untuk peningkatan kualitas gizi keluarga juga sebagai upaya untuk mengurangi ketergantungan akan jenis pangan tertentu.

Diversifikasi konsumsi pangan pada masyarakat Indonesia masih rendah, dikarena mayoritas masyarakat masih menggantungkan beras sebagai sumber pangan utamanya.Hal tersebut dapat kita lihat dari pola konsumsi beras yang mendominasi pola konsumsi pangan utama sebagian besar masyarakat Indonesia.Padahal, dalam konsep ketahanan pangan, diversifikasi pangan merupakan salah satu syarat untuk mencapai ketahanan pangan yang tangguh.

Penganekargaman konsumsi pangan atau diversifikasi konsumsi pangan diartikan sebagai pengurangan konsumsi beras yang dikompensasi oleh penambahan konsumsi bahan pangan yang berasal dari non-beras. Diversifikasi konsumsi pangan rumah tangga perlu terus didorong agar rumah tangga tidak terfokus pada satu jenis makanan pokok saja tetapi bagaimana memenuhi konsumsi pangan rumah tangga secara seimbang dalam jumlah dan komposisi yang cukup. Diversifikasi bahan pangan mencakup dua aspek yaitu diversifikasi ketersediaan, diversifikasi produksi dan diversifikasi konsumsi (Suhardjo, 1998). Diversifikasi pangan erat kaitannya dengan peningkatan kualitas sumber daya manusia, pembangunan pertanian di bidang pangan dan perbaikan gizi masyarakat. Menurut Suhardjo dan Martianto (1992) semakin beragam konsumsi pangan maka kualitas pangan yang dikonsumsi semakin baik. Oleh karena itu dimensi diversifikasi pangan tidak hanya terbatas pada pada diversifikasi konsumsi makanan pokok saja, tetapi juga makanan pendamping

Bagi masyarakat di daerah pesisir di Kota Bengkulu salah satu sektor yang sangat penting dalam penyedia pangan bagi sebagian besar masyarakat adalah hasil laut. Produksi total hasil perikanan tangkap pada tahun 2011 adalah sebesar 29.001,5 ton atau sebesar $36,22 \%$ dari potensi lestarinya. Rata-rata $68 \%$ dari total perikanan Kota Bengkulu bernilai ekonomis, sisanya sekitar 32\% adalah ikan non ekonomis. Sebanyak $90 \%$ dari total produk ekonomis tersebut dipasarkan ke luar daerah maupun ekspor, sisanya untuk konsumsi lokal. Pemanfaatan ikan non ekonomis dengan rata-rata sebanyak 32\% dari total produksi adalah sebagian kecil dikonsumsi segar dan sebagian besar lainnya diolah menjadi ikan kering/asin sebagai upaya pengawetan sehingga dapat dijadikan komoditi andalan daerah.

Sumber daya ikan dan hasil laut yang melimpah di Kota Bengkulu semestinya sudah bisa menjamin tercukupinya kebutuhan pangan masyarakat kelurahan Malebero dan kehidupan rumah tangga mereka lebih sejahtera. Akan tetapi keadaan perekonomian rumah tangga mereka jauh dari apa diharapkan. Tingkat pendapatan mereka relative lebih rendah, sehingga masyarakat nelayan masih diidentik dengan kemiskinan. Tingkat pendapatan nelayan yang masih rendah karena usaha yang ditekuni adalah sebagai penangkap ikan yang sangat tergantung dan dipengaruhi oleh musim dan kondisi cuaca yang tidak menentu. Pendapatan yang rendah dan tidak menentu akan sangat mempengaruhi pemenuhan pangan bagi anggota keluarga nelayan terutama dalam pemenuhan kebutuhan pangan pokok yaitu beras. Sebagian besar rumah tangga di RT. IV Kelurahan Malabero masih menjadinya beras dalam pemenuhan konsumsi pangan utama rumah tangga mereka. Hasil penelitian Tiera (2014) menunjukkan bahwa pola 
konsumsi pangan karbohidrat di Kota Bengkulu didominasi oleh beras dengan total pengeluaran terbesar dalam satu minggu dibandingkan dengan jenis pangan yang lainnya.

Untuk membantu permasalahan pemenuhan pangan bagi masyarakat RT.IV Kelurahan Malabero perlu ada upaya untuk pemenuhan konsumsi dan penganekaragaman pangan yang berasal dari bahan pangan lainnya. Di Kelurahan Malabero terdapat beberapa jenis tanamanpangan lain yang dapat dijadikan sebagai sumber pemenuhan kebutuhan pangan, diantaranya: 1). Jenis umbi-umbian. Tanamanjenisumbi-umbian terdiri atas ubijalar, ubi kayu, talas, dan ganyong; 2). Jenis Serealia. Jenis serelalia merupakan tanaman pangan yang sebenarnya sudah cukup banyak ditanam disebagian besar wilayah di Indonesia. Jenis tanaman. Serealia meliputi jagung, kedelai, cantel, dan sorgum. Sepertihalnya jenis umbi- umbian, tanaman jenis serealia belum dimanfaatkan optimal sebagai konsumsi pangan pokok (utama).

Masyarakat Kelurahan Malabero masih dominan mengkonsumsi beras dan terigu. Kualitas dan keberagaman konsumsi pangan masyarakat perlu ditingkatkan dan diimbangi dengan konsumsi protein, kacang dan umbi-umbian.Untuk merealisasikan pola konsumsi pangan yang beragam ini jelas perlu adanya upaya peningkatan konsumsi pangan lokal dan penyediaan teknologi pengolahan.

Keanekaragaman konsumsi pangan sangat penting untuk peningkatan kualitas gizi keluarga dan juga merupakan suatu upaya untuk mengurangi ketergantungan akan jenis pangan tertentu. Bagi sebagian orang yang sudah terbiasa pemenuhan konsumsinya dari beras kalau belum makan nasi maka rasanya belum terasa kenyang, sehingga tidak bisa dipungkiri ketergantungan masyarakat terhadap beras atau nasi putih masih sangat tinggi karena nasi selalu dianggap makanan pokok.Pandangan ini menyebabkan seolah-olah beras atau nasi adalah sumber karbohidrat yang tidak tergantikan oleh sebagian masyarakat nelayan di Kelurahan Malabero Kota Bengkulu.

Ketersediaan beras yang tidak sebanding dengan peningkatan jumlah permintaan beras dan mundurnya musim panen menyebabkan harga beras terus mengalami peningkatan.Akibatnya masyarakat berpenghasilan rendah seperti nelayan tidak mampu untuk membeli beras sebagai bahan pangan pokok.Padahal kondisi ketahanan pangan keluarga adalah terpenuhinya kebutuhan pangan baik dari segi jumlah, mutu, aman, merata, dan harganya terjangkau. Salah satu upaya untuk meningkatkan ketahan pangan keluarga adalah melalui penganekaragaman pangan, yaitu suatu proses pengembangan produk pangan yang tidak bergantung kepada satu jenis bahan saja, tetapi memanfaatkan beraneka ragam bahan pangan.

Dalam memenuhi kebutuhan pangan keluarga, salah satu faktor yang sangat penting dalam diversifikasi konsumsi pangan adalah melaksanakan product development. Produk ini merupakan upaya menciptakan suatu produk baru yang memiliki sifat, antara lain sangat praktis, tersedia dalam segala ukuran, kalau digunakan tidak ada sisanya dan mudah diperoleh di mana saja. Dengan semakin sibuknya kehidupan setiap anggota rumah tangga dan tidak cukupnya waktu untuk memasak makanan maka bentuk makanan yang siap olah dan siap santap merupakan pilihan yang terbaik. Diversifikasi konsumsi pangan seharusnya tidak hanya terbatas pada pangan pokok semata, namun pangan pelengkap lainnya sehingga mutu makanan yang dikonsumsi memberikan nilai gizi yang lebih baik (Sulaeman, 1995)

Dalam rangka mendukung program penganekaragaman makanan dan gizi keluarga, olahan ikan, aneka olahan jenis umbi-umbian dan olahan kacang-kacangan dapat 
dimanfaatkan secara optimal sebagai bahan pangan non beras karena umbi-umbian mengandung kalori dan karbohidrat.Potensi ikan, umbi-umbian dan kacang-kacangan di Kota Bengkulu tidak hanya dapat memperkaya keanekaragaman konsumsi pangan keluarga, namun juga mendatangkan peluang bisnis yang menguntungkan.Ikan, umbiumbian dan kacang-kacangan merupakan salah satu produk komoditas pangan yang dapat diolah menjadi beragam jenis panganan siap konsumsi maupun bahan baku industri. Ikan, aneka umbi-umbian dan kacang-kacangan mempunyai prospek yang cukup luas untuk dikembangkan sebagai substitusi beras dan untuk diolah menjadi makanan bergengsi (http://emi3astuti.blogspot.co.id). Pengubahan citra bahan pangan selain beras harus dilakukan melalui tahapan pengembangan produk atau pengolahan menjadi bentuk komoditas baru yang lebih menarik, dan perlu diperkaya dengan nutrisi.

Tujuan dari kegiatan pengabdian pada masyarakat ini adalah: 1). memberikan pengetahuan dan wawasan tentang pentingnya diversifikasi konsumsi pangan rumah tangga; 2). pelatihan tentang pembuatan beberapa produk olahan dari hasil laut seperti abon ikan, rolade ikan, dan bakso ikan tuna/Tenggiri; 3). pelatihan tentang pembuatan beberapa produk olahan dari non hasil laut dari umbi-umbian yang dikombinasikan dengan hasil laut seperti keripik umbi-umbian yang memiliki rasa udang dan ikan laut dapat dimanfaatkan untuk memenuhi konsumsi pangan keluarga; 4). pelatihan tentang pembuatan beberapa produk olahan dari non hasil laut lainnya, yaitu olahan makanan dari tahu dan tempe; 5). pelatihan tentang teknik pengemasan dan pelabelan produk sehingga produk ini bisa dijual dan dapat menambah penerimaan rumah tangga nelayan.

Manfaat yang diharapkan dari kegiatan penerapan ipteks ini adalah masyarakat pesisir khususnya ibu-ibu dan remaja putri di RT. IV Kelurahan Malabero, diantaranya: 1). Memiliki pengetahuan dan keterampilan dalam memproduksi aneka produk hasil laut dan produk non hasil laut: 1). memperoleh penghasilan yang dapat dipergunakan untuk menghidupi diri sendiri dan keluarganya; 2). Sarana untuk mengolah jiwa kewirausahaan yang akan menjadi bekal untuk berwirausaha, menambah wawasan dan pengalaman dalam berkarya serta menerapkan teknologi sederhana yang berhasil guna; 3). Tumbuhnya aneka mata pencaharian baru yang diusahakan masyarakat sehingga pengangguran dan kemiskinan masyarakat pesisir dapat berkurang.

\section{METODE PENGABDIAN}

Tahap-tahap kegiatan pengabdian pada masyarakat ini dimulai dengan persiapan, pelaksanaan, dan evaluasi.

Tahapan-tahapan yang dilakukan adalah sebagai berikut :

Tahap Persiapan meliputi :

1. Koordinasi dengan Tim Pelaksana Kegiatan tentang rencana yang akan dilakukan untuk melaksanakan kegiatan.

2. Mengurus izin kegiatan dengan membawa surat tugas dari Lembaga Pengabdian pada Masyarakat UNIB ke kantor kelurahan Malabero.

3. Berkoordinasi dengan ibu-ibu PKK mengenai jadwal kegiatan.

4. Menyiapkan tempat dan materi penyuluhan.

5. Menyiapkan alat-alat dan bahan yang digunakan untuk pelatihan.

6. Membuat dan memperbanyak handout tentang pembuatan produk makanan dari aneka hasil laut dan non hasil laut. 
Tahap Pelaksanaan meliputi :

1. Menggandakan handout yang dibagikan kepada peserta.

2. Menyampaikan materi pembekalan atau penyuluhan tentang :

a) Pentingnya Penganekaragaman konsumsi pangan rumah tangga.

b) Peranan hasil laut untuk keanekaragaman konsumsi rumah tangga

c) Peranan umbi-umbian sebagai pangan rumah tangga.

d) Aneka produk olahan hasil laut dan non hasil laut yang dapat dijadikan peluang usaha.

3. Praktek atau demonstrasi pembuatan aneka produk olahan hasil laut dan non hasil laut seperti abon ikan, rolade ikan, dan bakso ikan tuna, aneka olahan umbi-umbian yang diperkaya dengan rasa ikan dan udang seperti keripik talas, keripik ubi kayu, dan keripik ubi jalar, serta keripik tempe rasa ikan.

Evaluasi

Evaluasi dilaksanakan setelah pelatihan dilakukan dengan cara :

1. Wawacara peserta secara langsung dan pengisian angket.

Dari angket tersebut tergambar kekurangan-kekurangan kegiatan pelatihan dan masukan serta saran dari peserta, sehingga kekurangan tersebut dapat langsung diperbaiki pada kegiatan berikutnya.

2. Selain itu, untuk menilai keberhasilan program kegiatan ini adalah :
a) $80 \%$ peserta yang diundang hadir dalam pelatihan.
b) Terlaksananya seluruh kegiatan pelatihan kewirausahaan.
c) $40 \%$ peserta mampu mengembangkan usaha ekonomi produktif dengan pendampingan dari tim pengabdian pada masyarakat.
d) Pernyataan kepuasan dari peserta pelatihan, dan pemerintah setempat.

Metode pendekatan yang digunakan untuk mencapai tujuan yang diharapkan pada kegiatan penerapan ipteks ini adalah sebagai berikut:

A. Penyuluhan.

Peserta penyuluhan berjumlah 20 orang yang terdiri dari ibu-ibu rumah tangga dan remaja putrid RT. IV Kelurahan Malabero Kota Bengkulu. Penyuluhan (penyampaian materi), terutama tentang pentingnya penganekaragaman konsumsi pangan rumah tangga, baik dari non hasil laut.

B. Praktek, yaitu

1. Pembuatan aneka olahan hasil laut, yaitu pembuatan abon, rolade, dan bakso.

2. Pembuatan aneka olahan umbi-umbian diperkaya dengan rasa ikan dan udang seperti keripik talas, keripik ubi kayu, dan keripik ubi jalar.

3. Pembuatan keripik tempe rasa ikan dan udang dan sate tahu

C. Tahapan pelaksanaan

\section{Tahap Persiapan}

Pada tahap ini dilaksanakan beberapa kegiatan seperti pengurusan izin kegiatan, pemantapan rencana pelatihan, pembuatan format evaluasi, observasi ke lokasi, pembelian bahan dan peralatan.

\section{Tahap Pelatihan}

Metode utama yang ditempuh dalam kegiatan ini adalah : 
Memberikan penyuluhan tentang pentingnya penganekaragaman konsumsi rumah tangga.

1. Pembuatan aneka olahan hasil laut, yaitu pembuatan abon, rolade, dan bakso.

A. Abon ikan

Abon ikan merupakan salah satu bentuk produk olahan dan awetan ikan. Pembuatan abon dilandasi adanya produk yang melimpah atau ikan kurang diminati jika dikonsumsi langsung. Bahan-bahan yang digunakankan yaitu daging ikan tuna 5 $\mathrm{kg}$, gula merah 200g, santan, bawang merah 200g, bawang putih $100 \mathrm{~g}$, ketumbar 40g, cabai merah $50 \mathrm{~g}$, dan minyak goreng.

Cara pembuatan abon :

1) Ikan tuna dibersihkan dari sirip, patil dan isi perutnya, lalu cuci bersih.

2) Kukus ikan tuna hingga matang, kemudian dinginkan.

3) Hancurkan dagingnya dengan gilingan daging.

4) Haluskan bumbu yang telah disiapkan, lalu tumis hingga wangi.

5) Masukan daging ikan tuna yang telah dihancurkan dan tambahkan santan kental.

6) Goreng campuran bahan tersebut hingga berwarna cokelat tua.

B. Bakso ikan Tenggiri

Bahan bahan dan bumbu yang digunakan untuk pembuatan bakso yaitu 150 gram ikan tenggiri yang masih segar, 150 gram tepung sagu, 45 gram tepung terigu, 2 batang daun bawang (iris tipis), 1/2 sdt bawang putih halus, 1/2 sdt lada bubuk, 1/2 sdt vetsin, 1 sdt garam halus, air es secukupnya, 1 liter air untuk merebus, dan $1 / 2 \mathrm{~kg}$ minyak goreng.

Cara membuat bakso ikan tenggiri:

1) Ikan tenggiri yang sudah disiapkan kemudian ambil dagingnya saja, cuci sampai bersih lalu iris tipis dan tumbuk sampai halus simpan diwadah.

2) Masukkan tepung sagu, tepung terigu, irisan daun bawang, bawang putih yang sudah dihaluskan, lada bubuk, vetsin, dan garam secukupnya kemudian aduk-aduk sampai semua bahan tercampur rata.

3) Tuangkan air es secara perlahan sambil diaduk-aduk sampai adonan bakso agak kenyal.

4) Setelah itu bentuk bulat adonan bakso sesuai selera, lakukan sampai selesai simpan diwadah.

5) Panaskan air putih kemudian rebus adonan bakso yang sudah dibulatkan sampai bakso terapung, angkat dan tiriskan sejenak.

6) Panaskan minyak goreng kemudian masak bakso ikan sampai matang atau berwarna kekuningan, angkat dan tiriskan lalu lakukan penggorengan sampai selesai.

C. Rolade Ikan Tenggiri

Bahan yang digunakan untuk pembuatan rolade:

a) Bahan Kulit Rolade Ikan Tenggiri yaitu 2 sendok makan tepung terigu, 5 butir telur, 4 sendok makan air, Garam, dan lada.

b) Bahan Rolade Ikan Tenggiri yaitu $1 / 2 \mathrm{~kg}$ daging ikan tenggiri, cincang $1 / 2 \mathrm{~kg}$ udang cincang, 4 batang daun bawang, iris tipis, 200 gram wortel, potong dadu kecil, 200 gram buncis, iris $1 / 2 \mathrm{~cm}, 200$ gram bawang bombai, cincang, tumis 2 sendok makan saus tiram, 2 sendok teh wijen, 4 sendok makan tepung sagu, 200 gr putih telur, garam, dan lada. 
Cara Membuat Rolade Ikan Tenggiri :

1) Buat Dadar : campurkan telur, lada, garam, air, dan tepung terigu, aduk hingga rata, buatlah beberapa lembar dadar, masing-masing bergaris tengah atau berdiameter 22 $\mathrm{cm}$. Masak hingga matang, angkat dan sisihkan.

2) Kemudian campur semua bahan rolade ikan tenggiri, aduk hingga rata.

3) Siapkan dadar, tuang dan ratakan adonan rolade di atasnya (secukupnya). Gulung dadar rolade dengan adonan sambil dipadatkan. Kemudian bungkus rolade dengan alminium foil.

4) Kukus rolade ikan tenggiri kurang lebih selama 45 menit hingga matang, angkat dan dinginkan. Buka aluminium foil, rolade bisa disajikan dengan hanya dikukus atau bisa juga digoreng sampai berwarna kuning kecokelatan. Potong-potong miring kurang lebih setebal 1-2 cm.

5) Untuk membuat saus rolade : campurkan semua bahan saus menjadi satu. Setelah semua tercampur rata, masak dengan api sedang. Angkat dan dinginkan.

6) Rolade Ikan tenggiri dan sausnya siap disajikan.

2. Pembuatan aneka olahan umbi-umbian diperkaya dengan rasa ikan dan udang seperti keripik talas, keripik ubi kayu, dan keripik ubi jalar.

1) Pembuatan Tepung ubi kayu, ubi jalar, dan talas

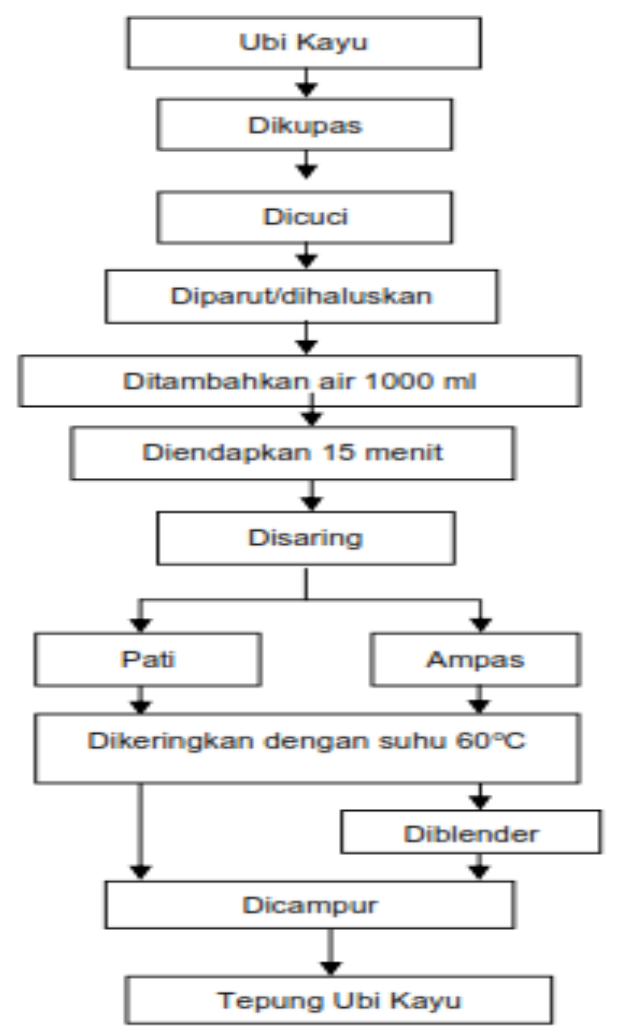


2) Pencampuran Ikan dengan Tepung umbi-umbian

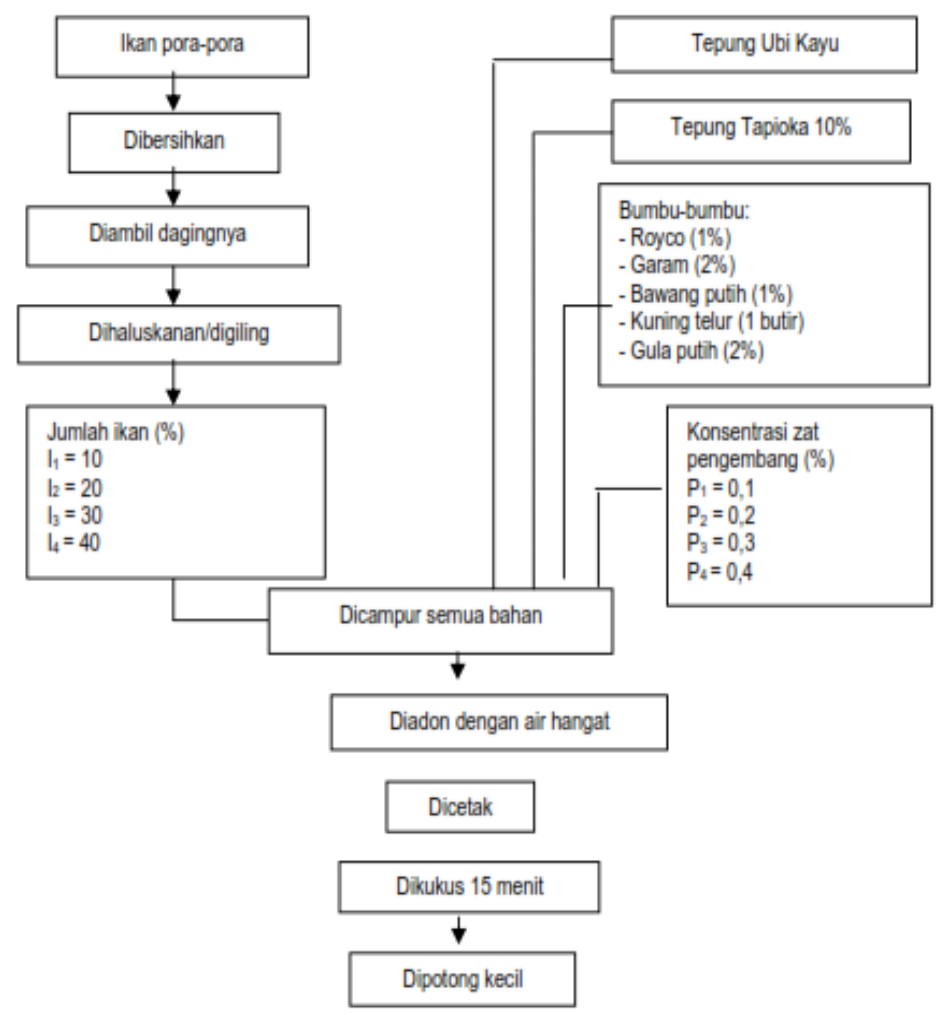

1. Pembuatan keripik tempe rasa ikan dan udang dan sate tahu

a) Bahan untuk membuat keripik tempe yaitu 3 kilogram tempe, iris tipis dengan bentuk sesuai selera, 600 gram tepung beras, 240 gram tepung maizena, 15 gram daun jeruk rajang tipis, 1,8 liter air putih, Minyak sayur secukupnya untuk menggoreng.

Cara pembuatan :

b) Bahan untuk pembuatan sate tahu

Bahan-bahan : Tusuk sate, Tahu, Kecap manis, Minyak goring, Bawang Goreng

Bahan bumbu haluskan :Cabe rawit hijau 15 buah, cabe merah besar 3 buah, bawang merah 5 butir, Bawang putih 3 butir, Kacang tanah goreng 200 gr, Penyedap rasa, gula merah $1 \mathrm{sdm}$, dan air.

Langkah-langkah cara membuat sate tahu :

1) Sediakan penggorengan kemudian tambahkan minyak dan masukan bumbu halus, tumis bumbu hingga tercium aroma wangi dan harum, masukan air sesuaikan dan diamkan hingga matang dan mendidih.

2) Masukan gula merah, penyedap rasa, garam, aduk rata. Angkat

3) Siapkan tusukan sate, lalu tusuk tahu, panggang tahu dengan menggunakan kompor dan besi panggangan dengan api yang sedang, jangan lupa sambil di bulak balik agar matangnya rata. Angkat

4) Sediakan piring dan letakan sate tahu lalu baluri dengan bumbu kacang, tuangkan kecap manis, taburi dengan bawang goreng.

5) Sate tahu siap untuk di sajikan 


\section{Keterkaitan}

Kegiatan ini tidak akan mungkin berhasil tanpa adanya keterkaitan dengan beberapa pihak lain. Dalam hal ini pihak kelurahan Malabero sebagai pihak yang mempunyai wilayah di mana kegiatan PPM hendak dilakukan, memberi dukungan dalam kegiatan ini dengan menyediakan tempat pelatihan. Selain itu Dinas Perikanan Kota Bengkulu diharapkan akan dapat memberikan dukungan melalui program-program yang terkait dengan usaha perikanan.

\section{Rancangan Evaluasi}

Hasil pelatihan dapat dievaluasi dari kondisi dan meningkatnya ketrampilan peserta. Evaluasi dilaksanakan setelah pelatihan dilakukan dengan cara wawacara peserta secara langsung dan pengisian angket. Dari angket tersebut tergambar kekurangan-kekurangan kegiatan pelatihan dan masukan serta saran dari peserta, sehingga kekurangan tersebut dapat langsung diperbaiki pada kegiatan berikutnya.

Selain itu, untuk menilai keberhasilan program kegiatan ini adalah :

1. $80 \%$ peserta yang diundang hadir dalam pelatihan.

2. Terlaksananya seluruh kegiatan penyuluhan dan pelatihan pembuatan produk olahan hasil laut dan non hasil laut.

3. $40 \%$ peserta mampu membuat dan mengembangkan usaha produk olahan hasil laut dan non hasil laut dengan pendampingan dari tim pengabdi.

4. Pernyataan kepuasan dari peserta pelatihan, dan pemerintah setempat.

Selanjutnya melakukan monitoring dengan pertemuan kembali pasca pelatihan.

Dalam monitoring ini didiskusikantentang berbagai halyang merekaalamipasca pelatihan.

\section{HASIL DAN PEMBAHASAN}

Konsumsi pangan rumah tangga merupakan banyaknya atau jumlah pangan yang dikonsumsi rumah tangga untuk memenuhi kebutuhan fisiologis, psikologis, dan sosiologis.Tujuan fisiologis adalah upaya untuk memenuhi keingian makan (rasa lapar).Tujuan psikologis adalah untuk memenuhi kepuasan emosional atau selera, dan Tujuan sosiologis adalah untuk memelihara hubungan manusia dalam keluarga dan masyarakat.Tingkat konsumsi pangan rumah tangga ditentukan oleh kuantitas dan kualitas pangan.Kuantitas pangan mencerminkan jumlah setiap gizi dalam suatu bahan makanan, sedangkan kualitas pangan mencerminkan zat gizi esensial yang terdapat dalam bahan pangan.Untuk mencapai keadaan gizi yang baik, maka unsur kuantitas dan kualitas harus dapat dipenuhi.

Dalam hal konsumsi pangan rumah tangga nelayan, permasalahan yang dihadapi tidak hanya mencakup keseimbangan komposisi, namun juga masih belum terpenuhinya kecukupan gizi. Selama ini pangan yang tersedia baru sampai mencukupi dari. Salah satu upaya upaya untuk mencapai keseimbangan jumlah dan komposisi konsumsi pangan rumah tangga nelayan adalah dengan diversifikasi pangan rumah tangga. Diversifikasi konsumsi pangan merupakan bentuk penganekaragaman pangan mencakup peningkatan jenis dan ragam pangan, baik dalam bentuk komoditas (bahan pangan), pangan semi olahan dan olahan, maupun pangan siap saji. Soetrisno dalam Budiningsih (2009), mendefinisikan diversifikasi pangan lebih sempit (dalam konteks konsumsi pangan) yaitu sebagai upaya menganekaragamkan jenis pangan yang dikonsumsi, mencakup pangan sumber energi dan zat gizi, sehingga memenuhi kebutuhan akan pangan dan gizi sesuai dengan kecukupan baik ditinjau dari kuantitas maupun kualitasnya. Sedangkan dari sisi 
permintaan atau konsumen, diversifikasi pangan berarti penganekaragaman pemenuhan kebutuhan terhadap komoditas pertanian (Bunasor, 1989)

Salah satu syarat mutlak suksesnya upaya diversifikasi pangan rumah tangga adalah perubahan perilaku rumah tangga nelayan. Hal ini dapat dilakukan melalui proses komunikasi, penyebaran informasi, dan edukasi untuk memasyarakatkan diversifikasi pangan rumah tangga. Dengan menyebarluaskan informasi tersebut diharapkan akan menumbuhkan kesadaran rumah tangga untuk mau mengurangi ketergantungan mereka terhadap pangan tertentu dan berangsur-angsur mengkonsumsi produk olahan pangan lainnya. Salah satu cara untuk menyebarkan informasi dan edukasi mengenai pentingnya penganekaragaman konsumsi pangan rumah tangga nelayan adalah melalui kegiatan pengabdian pada masyarakat.Kegiatan Pengabdian pada masyarakat ini dilaksanakan di RT. IV Kelurahan Malabero dari bulan Juni 2017 sampai dengan bulan Oktober 2017. Kegiatan ini melibatkan ibu-ibu rumah tangga, remaja putri, dan 2 orang orang mahasiswa Universitas Bengkulu. Kegiatan pengabdian pada masyarakakat diawalidengan mengadakan sosialisasi dan koordinasi dengan ibu-ibu rumah tangga nelayan dan remaja putri di RT. IV Malabero mengenai jadwal pelaksanaan kegiatan dan teknis pelaksanaan kegiatan.Dalam kegiatan pengabdian pada masyarakat ini, ibu-ibu rumah tangga dan remaja putri dilibatkan mulai dari proses perencanaan, proses pelaksanaan hingga proses monitoring dan evaluasi kegiatan.

Pelaksanaan kegiatan ini berjalan dengan baik sebagaimana yang diharapkan oleh pelaksana pengabdian, karena didukung oleh faktor ketersediaan bahan baku yang banyak, murah, dan mudah didapat, keingintahuan dari para peserta yang cukup tinggi, respon dari para peserta yang sangat baik, ini terlihat dari keikutsertaan masyarakat dalam setiap tahapan pelaksanaan kegiatan.
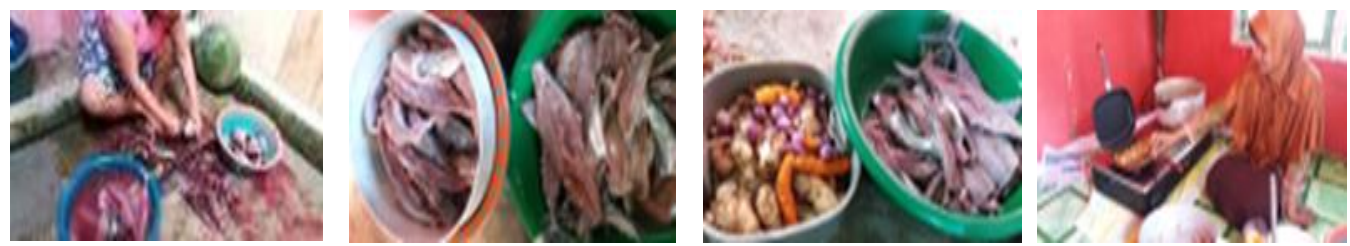

Gambar 1.Pembuatan Produk makanan dari olahan ikan tuna


Gambar 2. Pembuatan Produk makanan dari olahan umbi-umbian
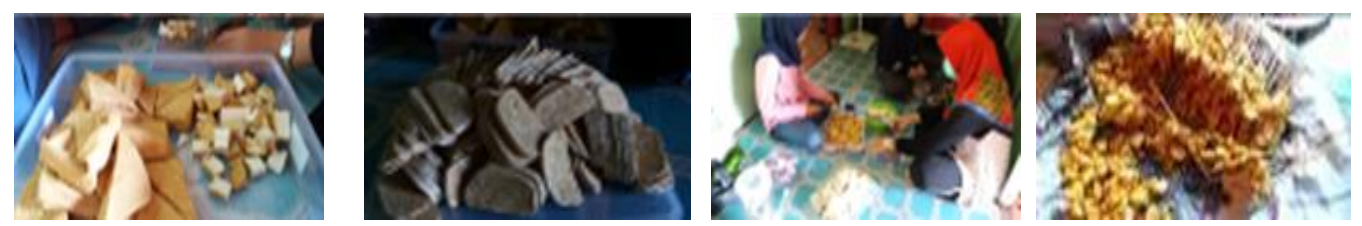

Gambar 3. Pembuatan Produk makanan dari olahan tahu tempe 
Dari kegiatan yang telah dilaksanakan diperoleh beberapa hasil, yaitu peningkatan pengetahuan dan keterampilan ibu-ibu rumah tangga dan remaja putri tentang cara pembuatan berbagai produk makanan dari olahan hasil laut dan non laut. Produk-produk yang dihasilkan adalah abon ikan tuna, bakso ikan tuna,rolade ikan tuna, keripik tempe, keripik ubi kayu, aneka keripik ubi, sate tahu, dan brownees tempe. Jumlah abon yang dihasilkan sebanyak $3 \mathrm{~kg}$, bakso ikan 50 tusuk, rolade ikan 10 buah, keripik ubi kayu dan ubi jalar rasa udang dan ikan masing-masing 3kg, sate tahu 100 tusuk, dan 1 buah browness tempe.

Tahap akhir dari kegiatan pengabdian ini adalah evaluasi. Kegiatan ini dilaksanakan dalam dua tahap. Evaluasi pertama ditujukan untuk mengetahui ketertarikan peserta terhadap olahan produk hasil laut dan non laut yang dipraktekkan, sedangkan evaluasi kedua untuk mengetahui keberlanjutan dari kegiatan ini. Evaluasi pertama dilakukan setelah praktek membuat produk. Sebagian besar ibu-ibu dan remaja putri sudah menguasai proses pembuatan produk. Hasilnya para peserta sangat puas dengan hasil yang diperoleh karena rasanya enak dan lezat. Namun perhitungan harga pokok produksi belum dilakukan pada pelaksanaan kegiatan ini. Evaluasi kedua bertujuan untuk mengetahui keberlanjutan dari kegiatan ini. Respon ibu-ibu terhadap kegiatan ini sangat baik sekali dan untuk waktu yang akan datang ibu-ibu berharap kegiatan ini terus berlanjut agar dapat memupuk semakin tumbuhnya jiwa berwirausaha aneka produk olahan hasil laut dan non laut, baik untuk ibu-ibu rumah tangga maupun remaja putri sehingga dapat dijadikan sumber usaha yang dapat menambah penghasilan keluarga.

\section{KESIMPULAN DAN SARAN}

\section{Kesimpulan}

Dari kegiatan pengabdian pada masyarakat "Penganekaragaman konsumsi pangan rumah tangga masyarakat pesisir di Kota Bengkulu melalui teknologi pengolahan produk hasil laut Dan non hasil laut“" masyarakat, khususnya ibu-ibu rumah tangga dan remaja putri di RT.IV Malabero Kota Bengkulu memperoleh peningkatan pengetahuan dan keterampilannya, diantaranya:

1. Peningkatan pengetahuan dan wawasan tentang pentingnya diversifikasi konsumsi pangan rumah tangga.

2. Peningkatan pengetahuan dan keterampilan dalam pembuatan beberapa produk olahan dari hasil laut seperti abon ikan, rolade ikan, dan bakso ikan tuna/Tenggiri.

3. Peningkatan pengetahuan dan keterampilan dalam pembuatan beberapa produk olahan dari non hasil laut dari umbi-umbian yang dikombinasikan dengan hasil laut seperti keripik umbi-umbian yang memiliki rasa udang dan ikan laut dapat dimanfaatkan untuk memenuhi konsumsi pangan keluarga.

4. Peningkatan pengetahuan dan keterampilan dalam pembuatan beberapa produk olahan dari non hasil laut lainnya, yaitu olahan makanan dari tahu dan tempe.

5. Peningkatan pengetahuan dan keterampilan dalam teknik pengemasan dan pelabelan produk sehingga produk ini bisa dijual dan dapat menambah penerimaan rumah tangga nelayan.

\section{Saran}

Kegiatan pelatihan bagi ibu-ibu rumah tangga dan remaja putri di daerah pesisir Kota Bengkulu, khususnya di Kelurahan Malabero Kota Bengkulu ini harus sering dilakukan secara kontinyu karena kegiatan ini memiliki manfaat yang besar untuk 
meningkatkan keterampilan sehingga dapat dijadikan sumber usaha yang dapat menambah penghasilan keluarga. Untuk mewujudkan hal ini diperlukan usaha pembinaan dan kerjasama dari semua pihak yang terkait.

\section{DAFTAR PUSTAKA}

Budiningsih, R, 2009, Faktor-faktor yang Berpengaruh Terhadap Diversifikasi Konsumsi Pangannon Beras di Kabupaten Magelang, Tesis S2, Universitas Diponegoro, Tidak dipublikasikan.

Bunasor, 1990, Diversifikasi dan Program Pembangunan Pertanian, Jakarta:Pustaka Sinar Harapan

http://emi3astuti.blogspot.co.id/2013/05/diversifikasi-pangan-berupa-kacang_12.html, diunduh tanggal 16 Februari 2016.

Sulaeman, DA, 2008, Analisis alokasi pengeluaran keluarga peserta dan bukan peserta proyek penanggulangan kemiskinan perkotaan di Desa Gardusayang, Kabupaten Subang, [Skripsi], Bogor: Fakultas Pertanian, Institut Pertanian Bogor.

Suhardjo, 1998, Sosio Budaya Gizi, Departemen pendidikan dan Kebudayaan, Direktorat Jenderal Pendidikan Tinggi Pusatantar Universitas Pangandan Gizi.

Suhardjo dan D. Martianto, 1992, Analisis Tipologi Makanan Pokok, PSKPG.LP-IPB, Bogor.

Tiera, F.K, Ketut, S, dan Bambang, S, 2014, Pola Konsumsi Mayarakat Pesisir Berbasis Karbohidrat di Kota Bengkulu: Aplikasi Model AIDS, Jurnal Agrisep, 13:14128837. 